\title{
Teaching the Effect of Flour on Mechanical Properties of Shrimp Shell Crackers 'Kerupuk' to High School Students
}

\author{
Sri Anggraeni, Alin Parliana Hotimah, Gabriela Chelvina Santiuly Girsang, Risti Ragadhita, Siti Nur \\ Hofifah, Asep Bayu Dani Nandiyanto*
}

Universitas Pendidikan Indonesia, Jl. Dr. Setiabudhi No. 229 Bandung, Indonesia anggraeni_said@upi.edu, ${ }^{2} a l i n p a r l i a n a @ u p i . e d u$, gabrielachelvina@upi.edu, ristiragadhita@upi.edu, sitinurhofifah@upi.edu, nandiyanto@upi.edu

\begin{abstract}
The study aims to analyze experimental demonstration teaching method using video on high school students' science learning outcomes and investigate the effects of variations of flour on mechanical properties of shrimp shell crackers 'kerupuk' (SSC). SSC is made by mixing boiled-crushed shrimp shells with seasonings and flour (maize, tapioca, sago, and wheat flour). After that, the dough is shaped, steamed, cooled, sliced, dried in the sun, and fried with cooking oil. To analyze the SSC's mechanical properties, hardness, and puncture strength test is taken, and observation with an optical microscope is conducted. Students' understanding is assessed through a 10-pretestposttest question supported by a learning video, where the research subjects are 17 high school students in Indonesia. The results show that SSC with sago flour is the crispest cracker, followed by SSC with maize, wheat, and tapioca flour, respectively. The flour is affecting the expansion, retrogradation, pores, crispness, and SSC color. There is an increase in students' understanding of the effect of flour in SSC after being given the learning video. This research demonstrates how the effect of flour in food and students' understanding of it.
\end{abstract}

Keywords: Teaching, Students, Flour, Shrimp shell, Crackers, Crispness

\section{Asep Bayu Dani Nandiyanto}

Departemen Pendidikan Kimia, Universitas

Pendidikan Indonesia, Jl. Dr. Setiabudi No. 229

Bandung, Indonesia

nandiyanto@upi.edu

\section{Introduction}

Shrimp shells are waste from processed shrimp that usually comes from households or food processing such as canning. Like other biomass waste, shrimp shells are difficult to degrade, thus polluting the environment (Khan and Nowsad, 2012). Shrimp shell has high protein content so it could be used as food ingredients to improve nutrition (Benhabiles, Salah, Lounici, Drouiche, Goosen, and Mameri, 2012; Percot, Viton and Domard, 2003). The addition of high protein ingredients such as prawn and fish are commonly used for making crackers (Neiva, Machado, Tomita, Furlan, Lemos Neto, and Bastos, 2019; Akonor, Dziedzoave, Buckman, Mireku Esssel, Lavoe, Tomlins, 2017). Therefore, shrimp shell could be made as crackers.

There are four steps involved to make crackers, such as preparation, cooking, cooling, and puffing the crackers dough (Taewee, 2011). The dough is cooked first by boiling, steaming, or extrusion. The purpose of this step is to gelatinized the dough. After that, the cooked dough is cooled and sliced into the desired shape. The next crucial step is puffing. Puffing is the heating process that aims to evaporate water and creates pressure to push the matrix polymer, allowing expansion. The crackers characteristic is influenced by how the dough experiences this process.

In general, the ingredients affecting the characteristics of crackers. One of them is flour. Flour affects crackers' color, swelling power, retrogradation, porosity, gelatinization, leaching process, viscoelasticity, bulk density, expansion, and mechanical properties. Several studies have reported the effects of flour in cassava cracker (Saeleaw and Schleining, 2010), fish cracker (King, 2002), jackfruit cracker (Mustapha, Rahmat, Ibadullah, and Hussin, 2015), green banana cracker (Wang, Zhang, and Mujumdar, 2012), Coleus tuberosus cracker (Nugraheni, Hamidah, and 
Auliana, 2017), and beef cracker (Igene, Salami, Nkama, Negbenor, and Obinomen, 2015). However, the study of flour effects on mechanical properties of SSC has not been well reported.

The use of shrimp shells and the influence of flour variations in crackers can be studied by students, especially high school students taking science program. To illustrate the significance of food chemical composition, this subject matter is interesting to study. The teaching process could be done by using the experimental demonstration method. Experimental demonstration method is a teaching method by demonstrating items, events, rules, and the sequence of activity, either directly or through teaching media that are compatible with the presented material and could increase students' understanding (Handayani, Hufad, Tukimin, Rochyadi, and Nandiyanto, 2020; Hidayat, Rahmat, Fattah, Rochyadi, Nandiyanto, and Maryanti, 2020; Nandiyanto, Raziqi, Dallyono, and Sumardi). In this study, we use an experimental demonstration method using video as the learning media.

Therefore, this research's novelty is the evaluation of learning outcomes regarding the effect of maize, tapioca flour, wheat, and sago flour on the mechanical properties of SSC. In general, by knowing the appropriate flour for a product, we could control the desired mechanical properties. We use four types of flour that are commonly used to provide more information on the effects of flour on SSC.

The study aims to analyze the experimental demonstration teaching method using video on high school students' science learning outcomes and investigate the effect of various flour on the mechanical properties of shrimp shell crackers 'kerupuk' (SSC). The level of students' understanding is assessed by using 10-pretest-posttest questions. Students are given pretests to assess their abilities, a learning media in the form of video, and posttest to reassess student abilities. This research is useful for informing the results of using various flour in SSC and students' understanding of it.

\section{Method}

\subsection{The Making of SSC}

Shrimp shells for this study are collected in Bandung, Indonesia. The shrimp shells are cleaned, boiled for 30 minutes, and saw-milled. Salt, garlic, and $40 \mathrm{~g}$ of flour are mixed. To analyze the effect of flour on SSC's mechanical properties, we made four batches of SSC made from maize, tapioca flour, wheat flour, and sago flour. We only used one type of flour per batch. After the ingredients are mixed, the dough then shaped, steamed for one hour, cooled, sliced, dried using sunlight for four days, and fried with cooking oil for 30 seconds.

\subsection{The Mechanical Properties Analysis}

In this study, hardness and puncture strength test are carried out to analyze SSC's mechanical properties. Screw Stand Test Instrument (Model I ALX-J, China) equipped with a digital force gauge instrument (Model HP-500, Serial, No H5001909262) was used for the hardness test. The test is conducted by applying a compressive force to the SSC, producing a curve showing SSC's texture profile. Hardness is expressed by the curve peak value (maximum force applied) in Newton (N) units. In addition, the puncture strength test is done by using the Shore Durometer instrument (Shore A Hardness, In size, China). The puncture test is carried out by puncturing the SSC with a needle or probe, obtaining an SSC texture profile.

\subsection{Teaching Methods}

The subject in this study is 17 grade twelve science students in Bandung, Indonesia. We use experimental demonstration method using video as the learning media. There are three processes for determining the level of students' understanding. In the first stage, students are given a 10-questions pretest to determine the students' knowledge about SSC and the effect of various flour in SSC. Thereafter, students are given a learning video that includes the explanation of using shrimp shells as crackers, the making of SSC, the theoretical effect of flour in food, and the analysis of mechanical properties test of SSC. Posttest is then given to find out whether there is an increase in students understanding. The pretest-posttest analysis is carried out using a score scale of 0 (wrong) and 1 (correct). The average score of each question is converted into $\%$ and tabulated.

\section{Results and Discussion}

\subsection{Mechanical Properties of SSC with various flour}

The pictures of SSCs using tapioca flour, sago flour, maize, and wheat flour is shown in Figure 1. Flour was affecting the appearance and color of the SSC. SSCs that are made using tapioca and sago flour have a white-yellow color with bumps along the surfaces. On the other hand, SSCs that are made using maize and wheat flour have a brown color and has a smoother surface. SSC made of wheat flour is darker in color compared to SSC made from maize. A similar result is obtained in the batter coating on chicken wings. The coating from wheat flour produced a darker color compared to rice and sago flour (Yusnita, Wan Aida, Maskat, and Aminah, 2007).

A high-temperature frying process leads to the denaturation and oxidation of fish protein, resulting in the darker color of the product (Sikorski, Pan, and Shahidi, 1994; Nurul, Boni, and Noryati, 2009). The presence of oil during the puffing process also influences the browning process. This may be due to the presence of lipid oxidation intermediate products in the Maillard reaction (Mastrocola, Munari, Cioroi, and Lerici, 2000). According to the Maillard reaction, the browning phenomenon is caused by the reaction between sugars and amino groups of proteins (Murata, 2020). Wheat flour has high carbohydrate content $(72,74-$ $85 \%$ ), so it has high sugar content (Wong and Lee, 2011; Kohajdová, Karovičová, and Magala, 2013). Moreover, the protein in SSC increases due to the shrimp shell. Compared to other flour that is used in this study, wheat flour has higher protein $(11,7 \%)$ and higher lipid content $(1,68 \%)$ (Wong and Lee, 2011). Therefore, SSC made from wheat flour has the darkest color compared to other samples. 


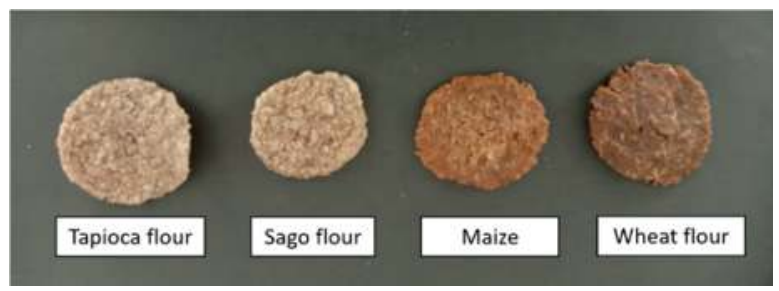

Fig. 1 Photographs of SSC from various flour

Besides, photos of SSC's physical appearance using a microscope are taken to analyze the surface and insides of SSC (Figure 2). SSC made from tapioca flour (Figure 2(a)), and sago flour (Figure 2(b)) have air pockets on the surface. However, the air pockets in SSC from sago flour are thinner than tapioca flour SSC. Moreover, the air pockets in sago flour SSC are more numerous and relatively smaller than tapioca flour SSC. According to observation, the air pockets are also found in the insides/core of SSC made from sago flour, whereas the air pockets in tapioca flour SSC are mainly on the surface. Air pockets are rarely found in wheat flour (Figure 2(c)) and maize SSCs (Figure 2(d)). However, more cracks are observed on SSC made from maize than SSC made from wheat flour.

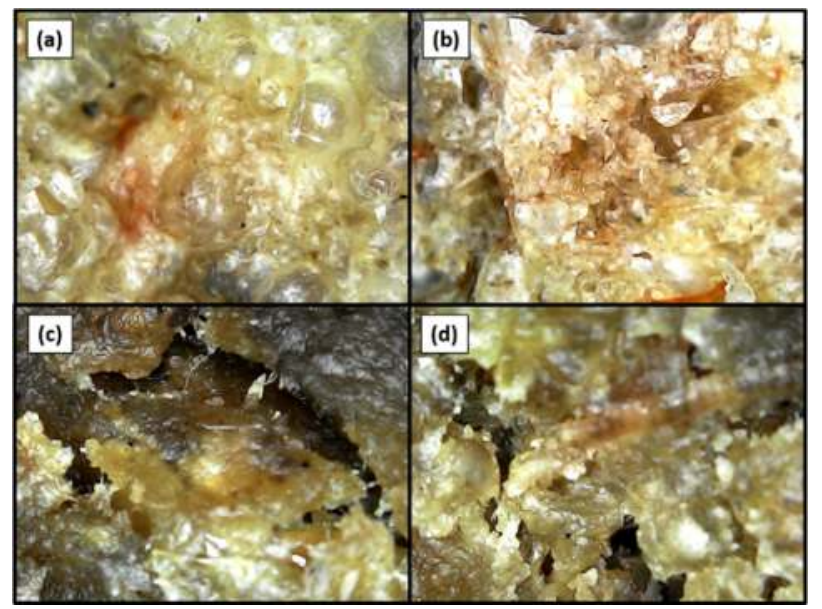

Fig. 2 Physical appearance of SSC made from tapioca flour (a), sago flour (b), wheat flour (c), and maize (d).

Compositions in the material influence the mechanical properties of the material (Nandiyanto, Fiandini, Ragadhita, Sukmafitri, Salam, and Triawan, 2020). This needs analysis of the mechanical properties of crackers.

The results of the hardness test are shown in Figure 3. The higher the force uses in the hardness test, the more difficult to break the SSC (low crispness). On the other hand, the higher force uses in the puncture strength shows that the SSC is more brittle (Table. 1). Both tests show that the crispest SSC is made with sago, maize, wheat, and tapioca flour, respectively.

SSC that is made from sago flour has the highest level of crispness due to the swelling process. SSC with sago flour has a larger granule size so they can bind more water (Cheow, Kyaw, Howell, and Dzulkifly, 2004). The dough's moisture is evaporated from the SSC during the puffing process, leaving pores or air bubbles on the cracker (confirmed by the microscope observation). The same result is also obtained from making cassava crackers with the addition of sago flour (Tongdang, Meenun, and Chainui, 2020).

However, SSC from sago flour tends to experience relatively less expansion than SSC made from tapioca flour. Sago flour has a higher amylose content, supporting retrogradation (Taewee, 2011). During retrogradation, amylose and amylopectin chains are disaggregated in a gelatinized phase (Wang, Li, Copeland, Niu, and Wang, 2015). The high rate of retrogradation resulted in a firmer gel, so the SSC is resisting expansion ( $\mathrm{SSC}$ 's diameter from sago flour is smaller compared to SSC from tapioca flour).

Although the observed expansion of SSC from maize is relatively lower than SSC from tapioca and sago flour, it has more cracks on the surface, confirming a higher rate of swelling and expansion compared to SSC from wheat flour. The cracks are formed during the puffing process, allowing water to evaporate from the dough. Therefore, it is more brittle than SSC from wheat flour.

SSC made from wheat flour has the smallest expansion compared to other flours. This is due to the protein content in the flour. Wheat flour has higher protein content than tapioca and sago flour. Protein in flour inhibited SSC expansion (Taewee, 2011). In theory, SSC from wheat flour is the hardest. However, SSC from wheat flour is the thinnest cracker, making it easier to shatter.

SSC made from tapioca flour has the highest expansion rate. This is confirmed by the air pockets or pores on the SSC's surface, diameter, and thickness. The protein content is smaller than wheat flour, allowing a higher rate of expansion (Taewee, 2011). Moreover, the high expansion rate replied to low amylose content in tapioca flour do not support retrogradation. Similar results are obtained in reference (Saeleaw and Schleining, 2010) that a bigger fraction of tapioca flour in composition to other flour results in higher expansion. Usually, a high expansion rate makes the SSC more porous, making it easier to crack when pressure is applied. However, in this study, SSC from tapioca flour has the most rigid texture. Tapioca starch produces firmer gel, thus making it difficult for moisture to escapes during the heating process. This is confirmed by microscope observation. Pores in SSC from tapioca flour are mostly found on the surface, informing the removal of moisture at the core of SSC rarely occurs. The least pores in the core made the SSC from tapioca flour has the least crisp texture.

The carbohydrate, lipid, and protein content affect mechanical properties. Those three components are positively increased the browning process and make the outer structure harder. Higher protein content inhibited the expansion of SSC, causing the SSC least crisp. 


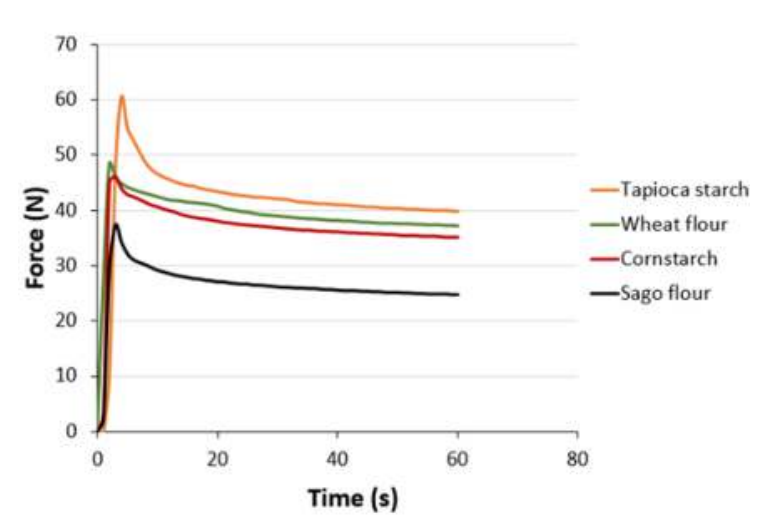

Fig. 3 Hardness test of SSC from various starch

Table 1. Puncture strength test result of SSC made from various flour

\begin{tabular}{|l|l|}
\hline \multicolumn{1}{|c|}{ Flour } & Average Score \\
\hline Tapioca flour & 33.83 \\
\hline Wheat flour & 46 \\
\hline Maize & 56 \\
\hline Sago flour & 73.17 \\
\hline
\end{tabular}

\subsection{Qualitative Analysis of Student}

Table 2 shows students' demographics of the average score of science subjects (Mathematics, Chemistry, Physics, and Biology), and Bahasa Indonesia. There is no significant difference between subjects' scores. Therefore, the students' mastery in each subject is mostly similar. The data also informs that the students have sufficient skills in science subjects.

Table 2. Students' report card scores

\begin{tabular}{|l|l|}
\hline \multicolumn{1}{|c|}{ Subject } & \multicolumn{1}{c|}{ Average Score } \\
\hline Mathematics & 80.69 \\
\hline Chemistry & 80.68 \\
\hline Physics & 81.04 \\
\hline Biology & 84 \\
\hline Bahasa Indonesia & 82.38 \\
\hline
\end{tabular}

Table 3 displays the score for each question in pretest and posttest. Pretest and posttest could provide the cognitive growth of students, improving the understanding of the learning content (Hayati, Bintari, and Sukaesih, 2018).

The question raises centered on how the content of carbohydrates, protein, and oil affects SSC properties. Based on the students' demographics, the students have sufficient skills in science subjects. However, the pretest score is relatively low, indicating insufficient students' understanding of the effect of carbohydrate, protein, and oil content on food. Nevertheless, pretest can act as a motivational factor or a direct teaching function. In general, pretest can raise the students' interest or attention to the coming events, such as learning experience or posttest (Kim and Willson, 2010). Pretest may alert the subjects to the related topics and selectively concentrate on what the researchers are intending to look at.

After the video is given, there is an improvement in the posttest score (11.76-52.94\%). Posttest allows students to recall and draw a conclusion from their lessons (Sakuraya, Shimazu, Imamura, Namba, and Kawakami, 2016). The learning video that is presented is capable of conveying messages using visual and auditory experience, enhancing students' learning process and outcomes (Warju, Ariyanto, Soeryanto, Hidayatullah, and Nurtanto, 2020). Indirectly, this could increase students' interest in subjects and boost learning motivation (Risdianto, Dinissjah, and Nirwana, 2020; Sotáková, Ganajoa, and Babincakova, 2020).

On questions $1^{*}, 3,4$, and 5 , the posttest score decreases or remains constant. In the video, the analysis and hardness result of SSC with different flour variations are described. Therefore, protein as an element affects hardness in food is more prominent and appealing in the video to students than carbohydrates and oils subject. Learning using the experimental demonstration method through instructional videos with a particular topic can improve students' understanding of more specific material. Using a thematic topic for a learning video also could encourage creativity in science (Munakata and Vaidya, 2015).

To analyze whether there is a significant difference between the pretest and posttest scores, a t-test is conducted. The t-test results show that the $t$ critical two-tailed value (2.26) is higher than the t statistic value (-1.89). Therefore, the learning video significantly increases the students' mastery in understanding the effect of flour on SSC's mechanical properties.

The learning video enhances the students' comprehension because it offers an overview of the SSC's mechanical properties and why the flour affects the SSC properties. In addition, the learning video provides a visual experience regarding the making of SSC.

Table 3. Comparison of the students' average score

\begin{tabular}{|c|l|l|l|l|}
\hline \multirow{2}{*}{$\begin{array}{c}\text { No } \\
\text { 1.* }\end{array}$} & \multicolumn{1}{|c|}{ Question } & \multicolumn{3}{|c|}{ Score (\%) } \\
\cline { 3 - 5 } & $\begin{array}{l}\text { Shrimp shell could } \\
\text { affect the hardness } \\
\text { of the crackers to } \\
\text { become harder. }\end{array}$ & 88.24 & Posttest & Gain \\
\hline & $\begin{array}{l}\text { Tapioca flour is } \\
\text { made from } \\
\text { cassava, and wheat } \\
\text { flour is made from } \\
\text { wheat. }\end{array}$ & 100 & 100 & -11.76 \\
\hline 3. & $\begin{array}{l}\text { Flour variations } \\
\text { that are made will } \\
\text { produce products } \\
\text { with different } \\
\text { levels of hardness. }\end{array}$ & 94.12 & 94.12 & 0.00 \\
\hline 4. & $\begin{array}{l}\text { Variations of flour } \\
\text { could produce } \\
\text { different savory } \\
\text { taste. }\end{array}$ & 76.47 & 76.47 & 0.00 \\
\hline 5. & $\begin{array}{l}\text { The content of } \\
\text { carbohydrates in }\end{array}$ & 47.06 & 47.06 & 0.00 \\
\hline
\end{tabular}




\begin{tabular}{|c|c|c|c|c|}
\hline & $\begin{array}{l}\text { food makes the } \\
\text { texture of the food } \\
\text { hard. }\end{array}$ & & & \\
\hline 6. & $\begin{array}{l}\text { The fat content } \\
\text { makes the food } \\
\text { taste savory. }\end{array}$ & 76.47 & 88.24 & 11.76 \\
\hline 7. & $\begin{array}{l}\text { The protein } \\
\text { content contained } \\
\text { in food affects the } \\
\text { hardness of food. }\end{array}$ & 23.53 & 76.47 & 52.94 \\
\hline 8. & $\begin{array}{l}\text { The crackers from } \\
\text { sago flour are } \\
\text { harder than } \\
\text { crackers from } \\
\text { wheat flour. }\end{array}$ & 35.29 & 52.94 & 17.65 \\
\hline 9. & $\begin{array}{l}\text { Crackers from } \\
\text { wheat flour are } \\
\text { savorier than } \\
\text { crackers from sago } \\
\text { flour. }\end{array}$ & 47.06 & 58.82 & 11.76 \\
\hline 10. & $\begin{array}{l}\text { From all } \\
\text { variations, the } \\
\text { crackers with the } \\
\text { hardest texture are } \\
\text { tapioca flour, } \\
\text { wheat flour, maize, } \\
\text { and sago, } \\
\text { respectively. }\end{array}$ & 64.71 & 94.12 & 29.41 \\
\hline
\end{tabular}

\section{Conclusion}

The teaching of the effect of starch flour on mechanical properties of SSC has been studied. Flour influences the swelling power, pores, expansion, color, crispness, and retrogradation of SSC. The researchers categorize the SSC based on the degree of crispness using hardness and puncture strength test. The crispest SSC is achieved by using sago flour, followed by maize, wheat, and tapioca flour. The results of the pretest-posttest show that the learning video improves students' understanding of the effect of starch flour on mechanical properties of SSC.

\section{Acknowledgements}

We would like to thank Universitas Pendidikan Indonesia for supporting this study. We acknowledged RISTEK BRIN (Grant: Penelitian Terapan Unggulan Perguruan Tinggi) and Bangdos Universitas Pendidikan Indonesia.

\section{References}

Akonor, P. T., Dziedzoave, N. T., Buckman, E. S., Mireku Essel, E., Lavoe, F., and Tomlins, K. I. (2017). Sensory optimization of crackers developed from high-quality cassava flour, starch, and prawn powder. Food science and nutrition, 5(3), 564-569.

Benhabiles, M. S., Salah, R., Lounici, H., Drouiche, N., Goosen, M. F. A., and Mameri, N. (2012). Antibacterial activity of chitin, chitosan and its oligomers prepared from shrimp shell waste. Food hydrocolloids, 29(1), 48-56.

Cheow, C. S., Kyaw, Z. Y., Howell, N. K., and Dzulkifly, M. H. (2004). Relationship between physicochemical properties of starches and expansion of fish cracker 'keropok'. Journal of Food Quality, 27(1), 1-12.
Handayani, D., Hufad, A., Tukimin, S., Rochyadi, E., and Nandiyanto, A. B. D. (2020). Teaching pH of Suspension Containing Colloidal Particles Suspension to Students with Deaf and Hard Hearing. Journal of Engineering Science and Technology, 15, 48-57.

Hayati, D. P., Bintari, S. H. and Sukaesih, S. (2018). Implementation of the practicum methods with guideddiscovery model to the student skill of science process. Journal of Biology Education, 7(1), 118-126

Hidayat, D. S., Rahmat, C., Fattah, N., Rochyadi, E., Nandiyanto, A., and Maryanti, R. (2020). Understanding Archimedes Law: What the Best Teaching Strategies for Vocational High School Students with Hearing Impairment. Journal of Technical Education and Training, 12(1).

Igene, J. O., Salami, L. I., Nkama, I., Negbenor, C. A., and Obinomen, S. A. (2015). Physicochemical and sensory properties of cassava starch-based fish and beef crackers (keropok). Journal of Raw Materials Research, 2(1), 26-33.

Khan, M., and Nowsad, A. K. M. A. (2012). Development of protein enriched shrimp crackers from shrimp shell wastes. Journal of the Bangladesh Agricultural University, 10(2), 367-374.

Kim, E. S., and Willson, V. L. (2010). Evaluating Pretest Effects in Pre-Post Studies. Educational and Psychological Measurement, 70(5), 744-759.

King, M. A. (2002). Development and sensory acceptability of crackers made from the big-eye fish (Brachydeuterus auritus). Food and Nutrition Bulletin, 23(3), 317-320.

Kohajdová, Z., Karovičová, J., and Magala, M. (2013). Rheological and qualitative characteristics of pea flour incorporated cracker biscuits. Croatian journal of food science and technology, 5(1), 11-17.

Mastrocola, D., Munari, M., Cioroi, M., and Lerici, C. R. (2000). Interaction between Maillard reaction products and lipid oxidation in starch-based model systems. Journal of the Science of Food and Agriculture, 80(6), 684-690.

Munakata, M., and Vaidya, A. (2015). Using project-and theme-based learning to encourage creativity in science. Journal of College Science Teaching, 45(2), 48-53.

Murata, M. (2020). Browning and pigmentation in food through the Maillard reaction. Glycoconjugate Journal, 1-10.

Mustapha, N. A., Farhanah Binti Rahmat, F., Wan Ibadullah, W. Z., and Meor Hussin, A. S. (2015) Development of jackfruit crackers: Effects of starch type and jackfruit level. International Journal on Advanced Science, Engineering and Information Technology, 5(5), 330-333.

Nandiyanto, A. B. D., Fiandini, M., Ragadhita, R., Sukmafitri, A., Salam, H., and Triawan, F. (2020). Mechanical and biodegradation properties of cornstarchbased bioplastic material. Materials Physics and Mechanics, 44, 380-391. 
Nandiyanto, A. B. D., Raziqi, G. Y., Dallyono, R., and Sumardi, K. (2020). Experimental Demonstration for Enhancing Vocational Students' Comprehension on Heat Transfer through Conduction and Radiation of Light Bulb. Journal of Technical Education and Training, 12(3), 189-195.

Neiva, C. R. P., Machado, T. M., Tomita, R. Y., Furlan, É. F., Lemos Neto, M. J., and Bastos, D. H. M. (2011). Fish crackers development from minced fish and starch: an innovative approach to a traditional product. Food Science and Technology, 31(4), 973-979.

Nugraheni, M., Hamidah, S., and Auliana, R. (2017). A Potential of Coleus tuberosus Crackers Rich in Resistant Starch Type 3 Improves Glucose and Lipid Profile of Alloxan-Induced Diabetic Mice. Current Research in Nutrition and Food Science Journal, 5(3), 308-319.

Nurul, H., Boni, I., and Noryati, I. (2009). The effect of different ratios of Dory fish to tapioca flour on the linear expansion, oil absorption, colour and hardness of fish crackers. International Food Research Journal, 16, 159-165.

Percot, A., Viton, C., and Domard, A. (2003). Characterization of shrimp shell deproteinization. Biomacromolecules, 4(5), 1380-1385.

Risdianto, E., Dinissjah, M. J. and Nirwana, M. K. (2020). The Effect of Ethno Science-Based Direct Instruction Learning Model in Physics Learning on Students' Critical Thinking Skill. Universal Journal of Educational Research, 8(2), 611-615.

Saeleaw, M., and Schleining, G. (2010). Effect of blending cassava starch, rice, waxy rice and wheat flour on physicochemical properties of flour mixtures and mechanical and sound emission properties of cassava crackers. Journal of Food Engineering, 100(1), 12-24.

Sakuraya, A., Shimazu, A., Imamura, K., Namba, K. and Kawakami, N. (2016). Effects of a job crafting intervention program on work engagement among Japanese employees: a pretest-posttest study. BMC psychology, 4(1), 49.

Sikorski, Z. E. and Pan, B. S. 1994. The effect of heat induced changes in nitrogenous constituents on the properties of seafoods. In Sikorski, Z. E., Pan, B. S., and Shahidi, F. (Eds.). Seafood Proteins, p. 84-98. New York: Chapman and Hall.

Sotáková, I., Ganajová, M. and Babincáková, M. (2020). Inquiry-Based Science Education as a Revision Strategy. Journal of Baltic Science Education, 19(3), 499-513.

Taewee, T. K. (2011). Cracker" Keropok": A review on factors influencing expansion. International Food Research Journal, 18(3), 855-866.

Tongdang, T., Meenun, M., and Chainui, J. (2008). Effect of sago starch addition and steaming time on making cassava cracker (Keropok). Starch-Stärke, 60(10), 568-576.

Wang, S., Li, C., Copeland, L., Niu, Q., and Wang, S. (2015). Starch retrogradation: A comprehensive review.
Comprehensive Reviews in Food Science and Food Safety, 14(5), 568-585.

Wang, Y., Zhang, M., and Mujumdar, A. S. (2012). Influence of green banana flour substitution for cassava starch on the nutrition, color, texture and sensory quality in two types of snacks. LWT-Food Science and Technology, 47(1), 175-182.

Warju, W., Ariyanto, S. R., Soeryanto, S., Hidayatullah, R. S. and Nurtanto, M. (2020). Practical Learning Innovation: Real Condition Video-Based Direct Instruction Model in Vocational Education. Journal of Educational Science and Technology (EST), 6(1), 79-91.

Wong, N., and Lee, C. Y. (2011). Relationship between population growth of the red flour beetle Tribolium castaneum and protein and carbohydrate content in flour and starch. Journal of economic entomology, 104(6), 2087-2094.

Yusnita, H., Wan Aida, W. M., Maskat, M. Y., and Aminah, A. (2007). Processing performance of coated chicken wings as affected by wheat, rice and sago flours using response surface methodology. International Journal Of Food Science and Technology, 42(5), 535-542. 